Journal for ImmunoTherapy of Cancer

\section{$T$ cell receptor repertoire characteristics both before and following immunotherapy correlate with clinical response in mesothelioma}

To cite: Vroman $\mathrm{H}$,

Balzaretti G, Belderbos RA, et al. T cell receptor repertoire characteristics both before and following immunotherapy correlate with clinical response in mesothelioma. Journal for ImmunoTherapy of Cancer 2020;8:e000251. doi:10.1136/ jitc-2019-000251

- Additional material is published online only. To view please visit the journal online (http://dx.doi.org/10.1136/jitc2019-000251).

HV and GB are joint first authors.

Accepted 26 February 2020

Check for updates

(c) Author(s) (or their employer(s)) 2020. Re-use permitted under CC BY-NC. No commercial re-use. See rights and permissions. Published by BMJ.

For numbered affiliations see end of article.

Correspondence to

Professor Rudi W Hendriks; r.hendriks@erasmusmc.nl

\section{ABSTRACT}

Background Malignant pleural mesothelioma (MPM) is a highly lethal malignancy in need for new treatment options. Although immunotherapies have been shown to boost a tumor-specific immune response, not all patients respond and prognostic biomarkers are scarce. In this study, we determined the peripheral blood T cell receptor $\beta$ (TCR $\beta$ ) chain repertoire of nine MPM patients before and 5 weeks after the start of dendritic cell (DC)-based immunotherapy.

Materials and methods We separately profiled $\mathrm{PD} 1^{+}$and $\mathrm{PD}^{-}{ }^{-} \mathrm{CD} 4^{+}$and $\mathrm{CD}^{+} \mathrm{T}$ cells, as well as Tregs and analyzed 70000 TCR $\beta$ sequences per patient.

Results Strikingly, limited TCR $\beta$ repertoire diversity and high average clone sizes in total $\mathrm{CD}^{+} \mathrm{T}$ cells before the start of immunotherapy were associated with a better clinical response. To explore the differences in TCR $\beta$ repertoire prior-DC-therapy and post-DC-therapy, for each patient the TCR $\beta$ clones present in the total $C D 3^{+} T$ cell fractions were classified into five categories, based on therapy-associated frequency changes: expanding, decreasing, stable, newly appearing and disappearing clones. Subsequently, the presence of these five groups of clones was analyzed in the individual sorted T cell fractions. DC-therapy primarily induced TCR $\beta$ repertoire changes in the $\mathrm{PD} 1^{+} \mathrm{CD} 4^{+}$and $\mathrm{PD} 1^{+} \mathrm{CD} 8^{+} \mathrm{T}$ cell fractions. In particular, in the $\mathrm{PD} 1^{+} \mathrm{CD} 8^{+} \mathrm{T}$ cell subpopulation we found high frequencies of expanding, decreasing and newly appearing clones. Conversion from a $\mathrm{PD} 1^{-}$to a $\mathrm{PD} 1^{+}$ phenotype was significantly more frequent in $\mathrm{CD}^{+} \mathrm{T}$ cells than in $\mathrm{CD}^{+} \mathrm{T}$ cells. Hereby, the number of expanding $\mathrm{PD}^{+}{ }^{+} \mathrm{CD} 8^{+} \mathrm{T}$ cell clones - and not expanding $\mathrm{PD} 1{ }^{+} \mathrm{CD} 4^{+} \mathrm{T}$ cell clones following immunotherapy positively correlated with overall survival, progression-free survival and reduction of tumor volume.

Conclusion We conclude that the clinical response to DC-mediated immunotherapy is dependent on both the pre-existing TCR $\beta$ repertoire of total $\mathrm{CD}^{+} \mathrm{T}$ cells and on therapy-induced changes, in particular expanding $\mathrm{PD}^{+}{ }^{+} \mathrm{CD} 8^{+} \mathrm{T}$ cell clones. Therefore, TCR $\beta$ repertoire profiling in sorted T cell subsets could serve as predictive biomarker for the selection of MPM patients that benefit from immunotherapy.

Trial registration number NCT02395679.

\section{INTRODUCTION}

Malignant pleural mesothelioma (MPM) is a highly lethal malignancy that is often caused by asbestos fiber inhalation. Current treatment consists of a combination chemotherapy with antifolate and platinum, with an overall survival (OS) of 13.3 months and therefore novel effective treatment options are urgently needed. ${ }^{1}$

Recent breakthroughs that use cancer immunotherapy to enhance immune activation have revolutionized cancer treatment. These include inhibition of immune checkpoint molecules such as PD1/PD-L1 and CTLA-4. ${ }^{2}$ However, MPM treatment with checkpoint inhibitors was found to be noneffective $^{3}$ or only effective in a subpopulation of patients, ${ }^{45}$ likely due to low numbers of tumor-infiltrating lymphocytes (TILs) ${ }^{6}$ and a highly immunosuppressive tumor microenvironment. $^{18}$

Compared with healthy individuals, in MPM patients circulating dendritic cells (DCs) are reduced in numbers and antigen-processing capacity, which is thought to contribute to the low numbers of TILs. ${ }^{9}$ Previously, we developed a DC-mediated immunotherapy for MPM with the aim to increase the number of TILs and tumor-directed T cells. ${ }^{10}$ Patients received multiple vaccinations with autologous DCs loaded with autologous tumor cell lysate. This strategy was safe and feasible and showed signs of clinical activity in patients. However, the limited availability of tumor material precluded treatment in many MPM patients. Therefore, vaccination with DCs loaded with allogeneic tumor lysate derived from five in vitro cultured clinical-grade human MPM cell lines was developed and proven safe and feasible in a phase I clinical 
trial. ${ }^{11}$ Hereby, MPM patients were vaccinated three times with DCs once every 2 weeks and received booster vaccinations at three and 6 months after start of treatment. As part of the dose escalation study, each cohort of three patients received 10,25 or 50 million DCs per vaccination. Objective radiographical responses were obtained, and one patient had a $\sim 70 \%$ tumor reduction at 6 weeks after the first DC vaccination. ${ }^{11}$ Multicolor flow cytometry revealed that $\mathrm{DC}$ vaccination induced an increase in the number of circulating $\mathrm{CD} 4^{+} \mathrm{T}$ cells, $\mathrm{CD} 8^{+} \mathrm{T}$ cells and $\mathrm{B}$ cells. ${ }^{12}$ Furthermore, the frequency of HLA-DR, PD1 and inducible T-cell costimulator (ICOS)-expressing $\mathrm{CD}^{+} \mathrm{T}$ cells and LAG3-expressing CD8 ${ }^{+} \mathrm{T}$ cells increased after DC vaccination. Notably, the highest frequency of HLA-DR and ICOS-expressing $\mathrm{CD}^{+} \mathrm{T}$ cells was found in the best responding patient. No major treatment-associated $\mathrm{T}$ cell receptor (TCR) repertoire shifts were detected by analysis of TCR $\beta$-chain complementarity-determining region 3 (CDR3) length. ${ }^{12}$

Recent TCR sequencing studies indicated that TCR $\beta$ clone frequency and diversity are affected by immunotherapies, such as checkpoint inhibitors in pancreatic ductal carcinoma, ${ }^{13}$ lung cancer,,${ }^{14}$ and melanoma. ${ }^{1617}$ Hereby, TCR $\beta$ repertoire changes, including expansion or contraction of $\mathrm{T}$ cell clones, correlated with clinical response. ${ }^{14}{ }^{18}$ Likewise, DC-therapy changed TCR $\beta$ clone frequency and diversity in glioma, ${ }^{19}$ melanoma ${ }^{20}$ and prostate cancer, ${ }^{21}$ although correlations with clinical response were not reported.

In this study, we performed quantitative next generation sequencing-based human TCR $\beta$ repertoire profiling of peripheral blood of MPM patients obtained prior-DC and post-DC vaccination. To gain insight into the DC immunotherapy-induced TCR $\beta$ repertoire changes in $\mathrm{PD}^{+}$and $\mathrm{PD}^{-}{ }^{-} \mathrm{CD} 4^{+}$and $\mathrm{CD} 8^{+} \mathrm{T}$ cells, as well as Tregs, we separately analyzed these five $\mathrm{T}$ cell subpopulations. We observed that TCR $\beta$ repertoire changes significantly correlated with patient survival, indicating the potential of TCR $\beta$ profiling as a biomarker of clinical response to DC-based immunotherapy.

\section{MATERIALS AND METHODS}

Study design of the DC-based immunotherapy, FACSsorting of T cell subsets, analysis of TCR $\beta$ repertoire and statistical evaluation are detailed in online supplementary materials and methods file.

\section{RESULTS \\ DC-therapy induces TCR $\beta$ repertoire changes specifically in $\mathrm{PD}^{+}{ }^{+} \mathrm{CD}^{+} \mathrm{T}$ cells}

To identify immunotherapy-induced TCR $\beta$ repertoire changes, we profiled fractions of total $\mathrm{CD}^{+}{ }^{+} \mathrm{T}$ cells, $\mathrm{PD} 1^{-}$ and $\mathrm{PD}^{+}{ }^{+} \mathrm{CD} 4^{+} \mathrm{T}$ cells, $\mathrm{PD} 1^{-}$and $\mathrm{PD} 1^{+} \mathrm{CD}^{+} \mathrm{T}$ cells and Tregs from peripheral blood of nine MPM patients preDC-therapy and 5 weeks post-DC-therapy (see online supplementary figure S1 for gating strategy). The numbers of retrieved TCR $\beta$ sequences varied across the $\mathrm{T}$ cell fractions (see online supplementary figure S2). To normalize the reads per $\mathrm{T}$ cell fraction, we used 25000 quality-filtered, randomly selected sequences per sample for the total $\mathrm{CD}^{+} \mathrm{T}$ cell fractions and 2000 sequences for the individual $\mathrm{T}$ cell subpopulations.

The $\mathrm{PD}^{-}$and $\mathrm{PD}^{+} \mathrm{CD}^{+} \mathrm{T}$ cell fractions showed the largest degree of clonal expansion, given their highest average clone size, both pre-therapy and post-therapy (figure 1A). The $\mathrm{PD}^{+} \mathrm{CD}^{+} \mathrm{T}$ cell fractions showed the highest numbers of highly expanded clones (HECs; clones with a frequency $\geq 0.5 \%$ ) (figure $1 \mathrm{~B}$ ). The HECs accounted for $46.2 \%( \pm 12.8 \%)$ and $49.7 \%( \pm 9.2 \%)$ of the total repertoire in $\mathrm{PD}^{-}$and $\mathrm{PD}^{+} \mathrm{CD}^{+} \mathrm{T}$ cells, respectively, and was in the range of $2.7 \%-16.2 \%$ for the $\mathrm{CD} 4^{+} \mathrm{T}$ cell and Treg fractions (figure 1C).

Importantly, DC-therapy mainly induced changes in the $\mathrm{PD}^{+} \mathrm{CD}^{+} \mathrm{T}$ cell population, as specifically in this fraction-and not in any of the other subpopulationsthe average TCR $\beta$ clone size tended to be increased. Additionally, the numbers of retrieved HECs significantly decreased, and the impact of the first dominant clone increased after DC-therapy (figure 1A-D). We saw this DC therapy-induced increase in the impact of dominant clones also when we analyzed the top five or 10 HECs (data not shown). This indicates that the most dominant clones increased in impact at the cost of the less dominant clones, apparently without affecting the cumulative impact of the HECs on the total repertoire.

\section{High average TCR $\beta$ clone sizes prior to DC-therapy correlate with favorable clinical responses}

When we investigated the total $\mathrm{CD}^{+} \mathrm{T}$ cell fractions in more detail, we found that DC-therapy had no detectable effect on the impacts of the clonal sizes, $V \beta$ usage, $V \beta-J \beta$ recombination frequencies, mean TCR $\beta$ CDR3 length or charge (see online supplementary figure S3A-E). Interestingly, the values for the average TCR $\beta$ clone size in the total $\mathrm{CD}^{+} \mathrm{T}$ cell fractions prior to DC-therapy were positively correlated with both OS $\left(\mathrm{p}=0.0186 ; \mathrm{r}^{2}=0.57\right)$ and progression free survival (PFS) $\left(p=0.0227 ; r^{2}=0.52\right)$ (figure 2A,B). Such a positive correlation was not observed after DC-therapy (see online supplementary figure S4A,B). We also did not find correlations between OS or PFS and TCR $\beta$ clone size in the $\mathrm{CD} 4^{+}, \mathrm{CD} 8^{+} \mathrm{T}$ cells or Treg subpopulations (data not shown).

\section{DC-therapy selectively induces expanding and newly appearing $\mathrm{PD}^{+}{ }^{+} \mathrm{CD}^{+}$and $\mathrm{PD1}{ }^{+} \mathrm{CDB}^{+} \mathrm{T}$ cell clones}

Next, we linked the TCR $\beta$ sequences present in the total $\mathrm{CD}^{+} \mathrm{T}$ cell fraction to those in the sorted T cell subpopulations, using their unique CDR3 sequences. When we focused on the 25 most dominant TCR $\beta$ clones present in the $\mathrm{CD}^{+} \mathrm{T}$ cell population, we observed that for all patients the majority of these clones could be retrieved in multiple $\mathrm{T}$ cell subpopulations, particularly in both the $\mathrm{PD}^{+}$and in the $\mathrm{PD} 1^{-} \mathrm{CD} 8^{+} \mathrm{T}$ cell fraction. The TCR $\beta$ clone distribution over the $\mathrm{T}$ cell subpopulations was 


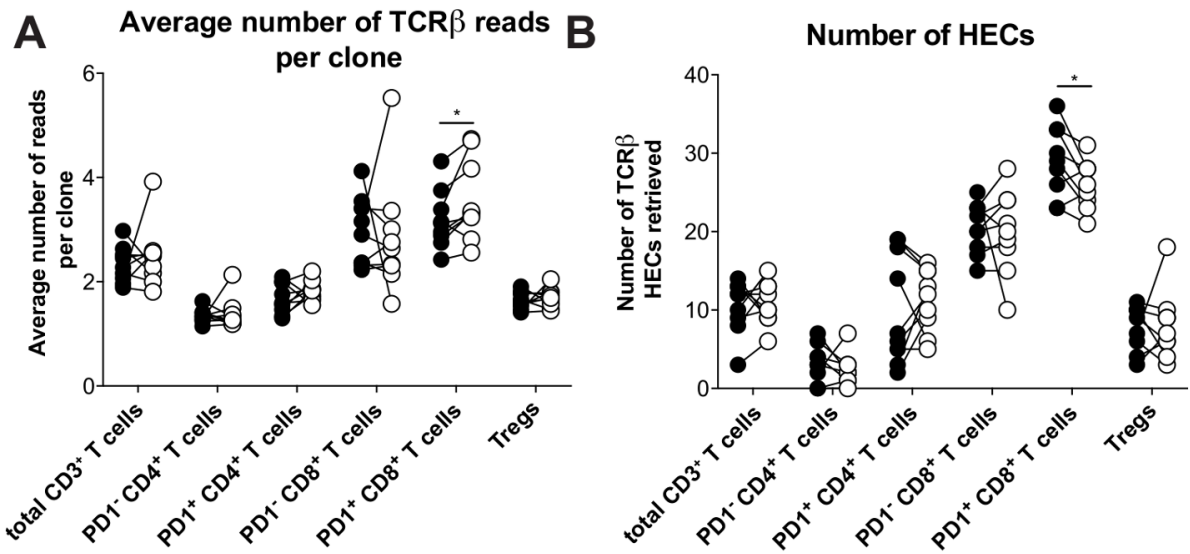

C Impact all HECs

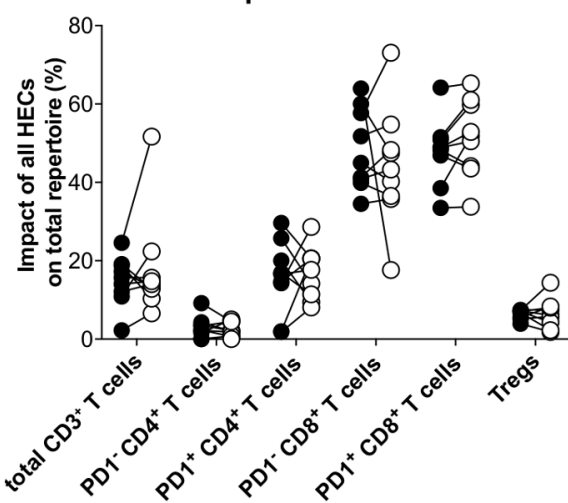

Impact first dominant clone

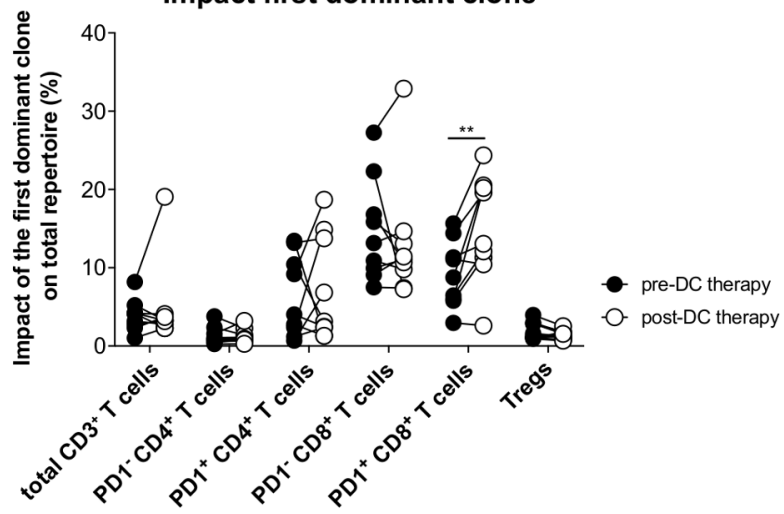

Figure 1 Characteristics of the TCR $\beta$ repertoire before and after DC-therapy. Analysis of 25000 TCR $\beta$ sequence reads (for the total $\mathrm{CD}^{+} \mathrm{T}$ cell fraction) and $2000 \mathrm{TCR} \beta$ sequence reads (for all other T cell fractions indicated). (A) Average clone size, shown as the average numbers of reads per clone; (B) numbers of highly expanded TCR $\beta$ clones (HECs) retrieved; (C) impact of all HECs on the total repertoire; (D) impact of the first dominant clone on the total repertoire. Each symbol represents values for a sorted T cell fraction, either pre-DC-therapy (closed circle) or post-DC-therapy (open circle). Paired samples are shown connected by black lines. Significance after paired t-test is shown in each graph, with ${ }^{*} p<0.05$. $P$ values were corrected for multiple testing, using the Benjamini and Hochberg False Discovery Rate. DC, dendritic cell; TCR $\beta, T$ cell receptor $\beta$.

similar in pre-DC-therapy and post-DC-therapy samples (figure 3A). For all patients only a small proportion of the clones were retrieved in the $\mathrm{CD} 3^{+} \mathrm{T}$ cells only.
To explore the differences in TCR $\beta$ repertoire priorDC-therapy and post-DC-therapy, for each patient the
A

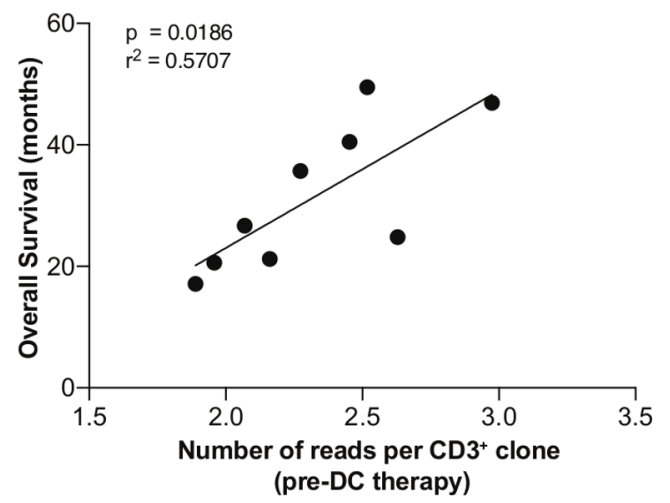

B

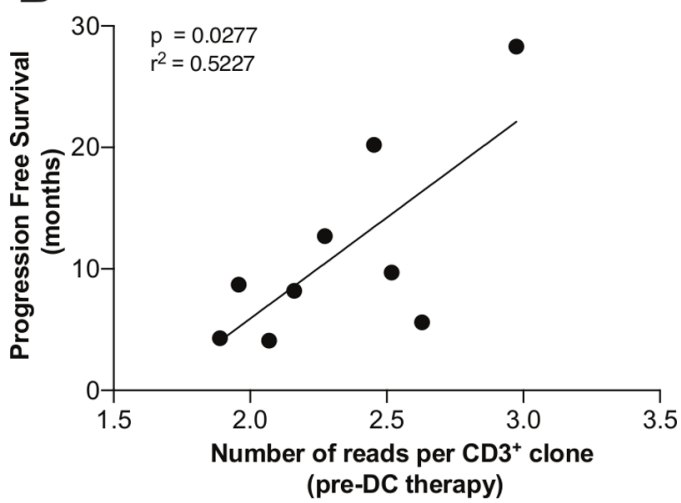

Figure 2 TCR $\beta$ clone sizes in total $C D 3^{+} T$ cells prior to DC-therapy correlate with favorable clinical responses. (A, B) Scatter plots of the number of reads per $\mathrm{CD}^{+}{ }^{+} \mathrm{T}$ cell clone pre-DC-therapy ( $\mathrm{x}$-axis) versus the overall survival in months ( $y$-axis in $A$ ) and the progression free survival in months ( $y$-axis in $B$ ). Linear regression curve fitting, $p$ values and $r^{2}$ are shown for each graph. DC, dendritic cell. 
A

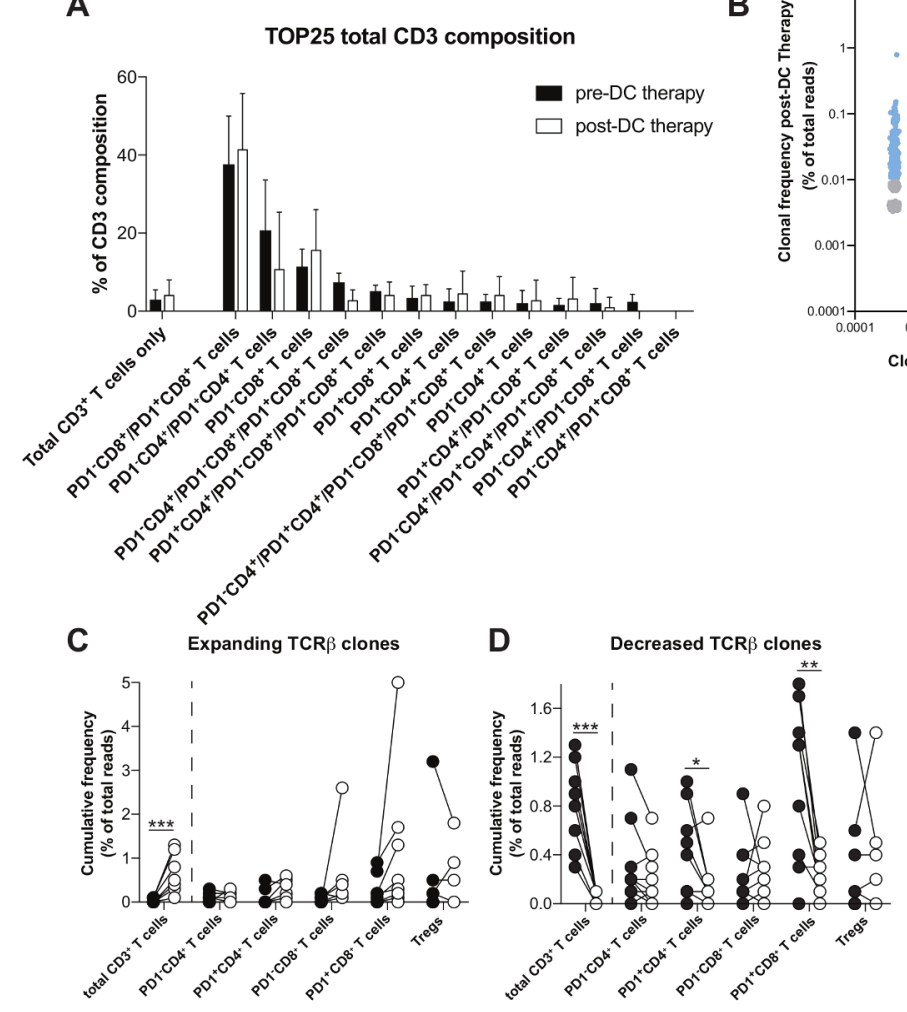

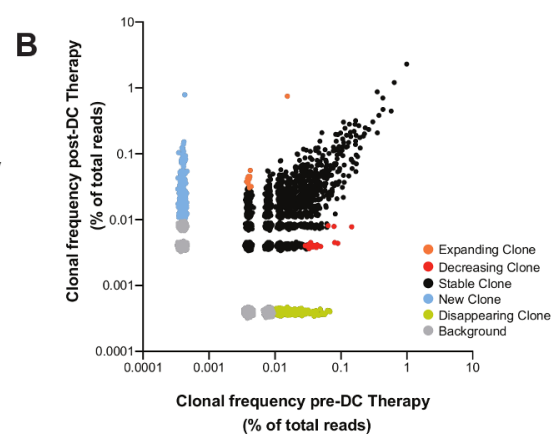

Figure 3 Clonal changes in the TCR $\beta$ repertoire after DC-therapy. (A) Composition of the 25 most dominant TCR $\beta$ HECs in the $\mathrm{CD}^{+} \mathrm{T}$ cell repertoire. Data for all individuals are plotted as mean values and SD using black bars for the repertoire pre-DCtherapy and white bars for the repertoire post-DC-therapy. (B) Representative plot showing the degree of overlap between the repertoire pre-DC-therapy (x-axis) and the repertoire post-DC-therapy (y-axis) in a total $C D 3^{+} T$ cell sample. Each dot represents one TCR $\beta$ clone and its clonal frequency in the total repertoire is shown as the percentage of the total number of 25000 reads in the sample. Clones are color coded, as indicated, according to their differential expression defined in Materials and Methods. Gray dots with a frequency $<0.01 \%$ were classified as background. (C, D, E) Cumulative frequencies of expanding (C), decreasing (D) and stable (E) clones present in the indicated T cell subpopulations pre-DC-therapy (closed circle) and postDC-therapy (open circle). Paired samples are shown connected by black lines. Significance of paired t-test is shown in each graph; ${ }^{* *} \mathrm{p}<0.01$ and ${ }^{* * *} \mathrm{p}<0.001$. $(\mathrm{F}, \mathrm{G})$ Cumulative frequencies of newly appearing $(\mathrm{F})$ and disappearing $(G) \mathrm{CD}^{+} \mathrm{T}$ cell clones after treatment. $(\mathrm{H}, \mathrm{l})$ Percentage of the newly appearing $(\mathrm{H})$ and disappearing $(\mathrm{l}) \mathrm{PD} 1^{+}$clones that are found as PD1 ${ }^{-}$before treatment, both in $\mathrm{CD} 4{ }^{+}$and $\mathrm{CD} 8{ }^{+} \mathrm{T}$ cells. Significance of $\mathrm{t}$-test is shown in each graph; ${ }^{*} \mathrm{p}<0.05,{ }^{* *} \mathrm{p}<0.01$ and ${ }^{* * *} \mathrm{p}<0.001$. $P$ values were corrected for multiple testing, using the Benjamini and Hochberg False Discovery Rate. DC, dendritic cell; TCR $\beta$, T cell receptor $\beta$ chain.

$\mathrm{TCR} \beta$ clones present in the total $\mathrm{CD}^{+} \mathrm{T}$ cell fractions were classified into five groups, based on their presence and fold change in clonal frequency: expanding, decreasing, stable, newly appearing and disappearing clones (figure 3B). Subsequently, the presence of these five groups of clones was analyzed in the individual sorted $\mathrm{T}$ cell fractions.

The TCR $\beta$ clones in the total $\mathrm{CD}^{+} \mathrm{T}$ cell populations that expanded on DC-therapy, were also expanded in the $\mathrm{PD}^{-}$and $\mathrm{PD}^{+} \mathrm{CD}^{+} \mathrm{T}$ cell fractions (figure $3 \mathrm{C}$ ).
Decreasing TCR $\beta$ clones were mainly retrieved in the $\mathrm{PD}^{+} \mathrm{CD}^{+}$and $\mathrm{PD}^{+} \mathrm{CD}^{+} \mathrm{T}$ cell fractions (figure $3 \mathrm{D}$ ). Stable TCR $\beta$ clones in the total $\mathrm{CD}^{+} \mathrm{T}$ cell populations had the largest cumulative frequency in the $\mathrm{PD}^{-}$and $\mathrm{PD} 1^{+} \mathrm{CD} 8^{+} \mathrm{T}$ cell fractions (figure $3 \mathrm{E}$ ), which was likely a reflection of the high average clone sizes and high numbers of HECs within $\mathrm{CD}^{+} \mathrm{T}$ cells (figure $1 \mathrm{~A}, \mathrm{~B}$ ).

TCR $\beta$ clones that were newly induced were particularly retrieved in the $\mathrm{PD} 1^{+} \mathrm{CD} 4^{+}$and $\mathrm{PD} 1^{+} \mathrm{CD} 8^{+} \mathrm{T}$ cell fractions (figure 3F). Disappearing TCR $\beta$ clones were present in 
all $\mathrm{T}$ cell fractions, but remarkably low in the $\mathrm{PD}^{-} \mathrm{CD}^{+} \mathrm{T}$ cell fractions (figure 3G).

To identify therapy-induced PD1 expression, we investigated whether new $\mathrm{PD}^{+}$clones within the $\mathrm{CD} 4^{+}$or $\mathrm{CD} 8^{+}$ $\mathrm{T}$ fractions could be retrieved in corresponding $\mathrm{PD}^{-} \mathrm{T}$ cell fractions prior DC-therapy. Only small proportions of the new TCR $\beta$ clones in the post-therapy $\mathrm{CD} 4^{+}$and $\mathrm{CD}^{+} \mathrm{PD}^{+} \mathrm{T}$ cell subpopulations $(\sim 2.7 \%$ and $\sim 10 \%$, respectively) were retrieved in the corresponding $\mathrm{PD}^{-} \mathrm{T}$ cell fractions (figure 3H). PD1 expression was apparently lost in $\sim 4.3 \%$ of $\mathrm{CD}^{+} \mathrm{T}$ cells and $\sim 8.8 \%$ of $\mathrm{CD}^{+} \mathrm{T}$ cells (figure 3I).

Taken together, we observed that DC-therapy mainly induced TCR $\beta$ changes, involving expanding, newly appearing and decreasing clones, in the $\mathrm{PD} 1^{+} \mathrm{CD} 4^{+}$and $\mathrm{PD} 1^{+} \mathrm{CD}^{+} \mathrm{T}$ cell subpopulations. Conversion from a $\mathrm{PD} 1^{-}$to a $\mathrm{PD} 1^{+}$phenotype or vice versa was significantly more frequent in $\mathrm{CD} 8^{+}$than in $\mathrm{CD} 4^{+} \mathrm{T}$ cells.

Numbers of expanding $\mathrm{PD1}^{+} \mathrm{CD8}^{+} \mathrm{T}$ cells clones correlate with clinical response to DC-therapy

Because DC-therapy mainly affected the TCR $\beta$ repertoires of $\mathrm{PD}^{+} \mathrm{CD}^{+}, \mathrm{PD}^{+}{ }^{+} \mathrm{CD} 8^{+}$and Treg cell fractions, we investigated the characteristics of these subpopulations in more detail. Only minor changes were found in $\mathrm{V} \beta$ gene usage, CDR3 charge and length between the five categories of TCR $\beta$ clones in these T cell subpopulations (see online supplementary figure S5). When we compared the amino acid sequences deduced from the RNA sequences of the new and expanding TCR $\beta$ clones across the nine patients, we identified no shared expanded clones and 13 shared new clones (see online supplementary table S1).

The numbers of expanding clones did not differ significantly between $\mathrm{PD}^{+} \mathrm{CD} 4^{+} \mathrm{T}$ cells, $\mathrm{PD}^{+} \mathrm{CD}^{+} \mathrm{T}$ cells and Tregs (see online supplementary figure S6A). The numbers of decreased and stable $\mathrm{PD} 1^{+} \mathrm{CD}^{+}$clones were significantly higher than decreased and stable $\mathrm{PD} 1^{+} \mathrm{CD} 4^{+}$ or Treg clones (see online supplementary figure S6B,C). The numbers of new and disappearing $\mathrm{PD}^{+} \mathrm{CD}^{+} \mathrm{T}$ clones were significantly lower than new and disappearing $\mathrm{PD} 1^{+} \mathrm{CD} 4^{+} \mathrm{T}$ cells or Tregs (see online supplementary figure $\mathrm{S} 6 \mathrm{D}, \mathrm{E})$. This is in line with the higher average number of reads per clone and the high impact of HECs in $\mathrm{PD} 1^{+} \mathrm{CD} 8^{+} \mathrm{T}$ cells (figure $1 \mathrm{~A}$ ).
Next, we assessed whether these TCR $\beta$ repertoire features were associated with clinical response. Strikingly, the number of expanding $\mathrm{PD} 1^{+} \mathrm{CD} 8^{+} \mathrm{T}$ cell clones significantly correlated with both OS $\left(\mathrm{p}=0.0441 ; \mathrm{r}^{2}=0.4616\right)$, PFS $\left(p=0.0041 ; r^{2}=0.7152\right)$ and radiographical change in tumor volume, measured at $\sim 6$ weeks after DC-therapy $\left(p=0.0351 ; r^{2}=0.4924\right) \quad$ (figure $\left.4 A-C\right)$. In contrast, these correlations were not observed with the number of expanding $\mathrm{PD}^{+} \mathrm{CD}^{+} \mathrm{T}$ cell clones (see online supplementary figure S7) or Tregs, nor in any of the other TCR $\beta$ clone categories (data not shown).

In conclusion, the number of expanding $\mathrm{PD} 1^{+} \mathrm{CD} 8^{+}-$ but not $\mathrm{PD}^{+} \mathrm{CD}^{+}-\mathrm{T}$ cell clones in MPM patients induced by DC-therapy significantly correlated with clinical response. This indicates that clinical efficacy of DC-therapy depends on a pre-existing $\mathrm{PD} 1^{+} \mathrm{CD} 8^{+} \mathrm{T}$ cell response.

\section{DISCUSSION}

Immunotherapeutic strategies have been shown to activate the immune system and to boost tumor-specific immune responses, ${ }^{2}$ but not all patients show clinical improvement. Sensitive methods to monitor the immune response after treatment and biomarkers predicting clinical benefit are scarce. To the best of our knowledge, we are the first to investigate TCR $\beta$ repertoire changes induced by DC-mediated immunotherapy in different $\mathrm{T}$ cell subpopulations. We studied peripheral blood samples from nine MPM patients who received autologous DCs loaded with allogeneic tumor lysate derived from cultured human MPM cell lines. This treatment strategy showed feasibility and promising clinical activity and immunological responses. ${ }^{112}$

For each patient we analyzed 70000 TCR $\beta$ sequences to characterize the TCR $\beta$ repertoire composition before and 5 weeks after the start of DC-therapy. We analyzed total $\mathrm{CD}^{+} \mathrm{T}$ cells and five fluorescence-activated cell sorting (FACS)-sorted subpopulations: $\mathrm{PD}^{-}$and $\mathrm{PD}^{+}{ }^{+} \mathrm{CD} 4^{+}$and $\mathrm{CD} 8^{+} \mathrm{T}$ cells and $\mathrm{CD} 25^{+} \mathrm{CD} 127^{\text {low }}$ Tregs. This analysis revealed that limited TCR $\beta$ repertoire diversity in total $\mathrm{CD}^{+} \mathrm{T}$ cells (inferred from a high number of reads per clone) before the start of immunotherapy was associated with a better clinical response. DC-based
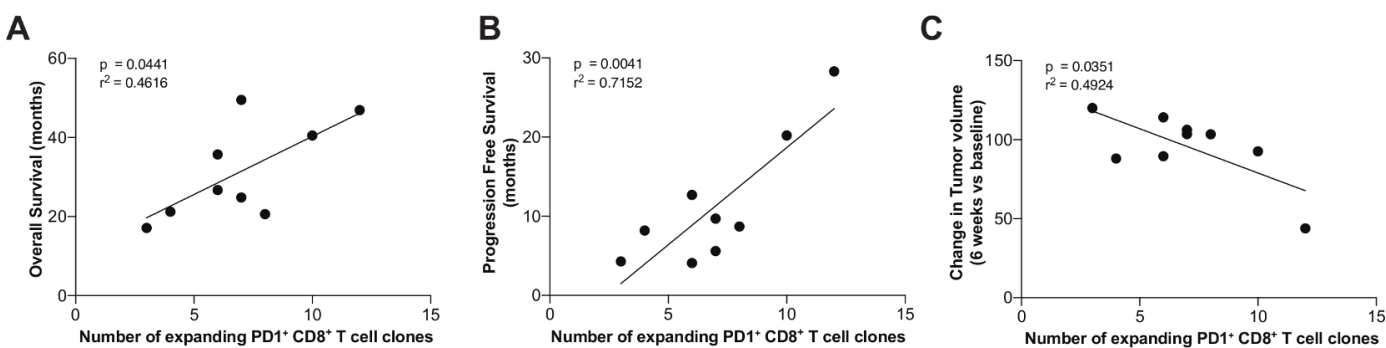

Figure 4 Correlations of TCR $\beta$ chain repertoires changes after dendritic cell-therapy with clinical outcome. (A, B, C) Number of expanding $\mathrm{PD} 1^{+} \mathrm{CD} 8^{+} \mathrm{T}$ cell clones after treatment versus overall survival in months $(\mathrm{A})$, progression free survival in months $(\mathrm{B})$ and the change in tumor volume at 6 weeks after treatment versus baseline (in $\mathrm{C}$ ). Linear regression curve fitting, $p$ values and $r^{2}$ are shown for each graph. 
immunotherapy induced TCR $\beta$ repertoire changes particularly in the $\mathrm{PD}^{+} \mathrm{CD}^{+}$and $\mathrm{PD}^{+} \mathrm{CD}^{+} \mathrm{T}$ cell subpopulations. These included expansion, contraction, appearance and disappearance of TCR $\beta$ clones, as well as apparent conversions from $\mathrm{PD}^{-}$into $\mathrm{PD}^{+}$and vice versa. Immunotherapy-induced repertoire changes were more extensive in $\mathrm{PD} 1^{+} \mathrm{CD} 8^{+} \mathrm{T}$ cells, given the significant increase in average clone size (figure 1A), changes in the numbers and impact of HECs (figure 1B,C) and the high levels of dynamics of PD1 expression (figure 3G,H). Importantly, the number of expanding $\mathrm{PD} 1^{+} \mathrm{CD} 8^{+}$-but not $\mathrm{PD}^{+} \mathrm{CD}^{+}-\mathrm{T}$ cell clones following immunotherapy positively correlated with OS, PFS and reduction of tumor volume. From these findings, we conclude that TCR $\beta$ repertoire profiling in both total $\mathrm{CD}^{+} \mathrm{T}$ cells and sorted $\mathrm{T}$ cell subsets could serve as predictive biomarker for clinical response in MPM patients to immunotherapy. Further studies including larger patient groups should show which of the two parameters correlates best with clinical outcome. We previously reported that all patients revealed strong responses to DCs loaded with tumor lysate and keyhole limpet hemocyanin 48 hours after DTH skin testing, providing evidence that DC-based immunotherapy is capable of inducting immunological response to tumor cells. This may also be supported by our current finding of 13 newly appearing clones that are shared between patients.

Our observation that a high average baseline TCR $\beta$ clone size is beneficial for a clinical response in MPM is in line with similar findings following anti-CTLA-4 treatment in pancreatic ductal adenocarcinoma patients ${ }^{13}$ and following anti-PD1 treatment in melanoma patients. ${ }^{22-24}$ Thus, the presence of circulating expanded $\mathrm{T}$ cell clones is generally beneficial for the clinical response to immunotherapy, irrespective of the treatment approach. Future studies should show whether these clones reflect a pre-existing tumor-specific T cell response. By contrast, in metastatic breast cancer patients low TCR diversity in conjunction with lymphopenia predicts poor OS, indicating that TCR diversity might reflect a measure of immunological fitness. ${ }^{25}$

DC-based immunotherapy in MPM patients induced selective expansion of TCR $\beta$ clones and a diversification of the repertoire driven by newly appearing clones, paralleling published observations in melanoma patients. ${ }^{20}$ Likewise, the number of expanding clones was increased in responding NSCLC patients treated with radiation therapy and CTLA-4 blockade, ${ }^{14}$ although in contrast to our study the $\mathrm{T}$ cell subset in which this expansion was most prominent was not determined. It is interesting that the frequency of expanding $\mathrm{PD} 1^{+} \mathrm{CD} 8^{+} \mathrm{T}$ cells was highest in the MPM patient with a substantial tumor volume reduction of $\sim 70 \%$. Also, when patients with pancreatic ductal adenocarcinoma were treated with anti-CTLA-4 antibodies, it was observed that patients with $>100$ expanded clones survived nearly three times longer than patients with lower numbers of expanding clones. ${ }^{13}$
Thus, TCR diversity have previously been correlated with clinical outcome for checkpoint inhibitor immunotherapy. ${ }^{13} 14222426$ In this context, it is important to note that clinical studies using checkpoint inhibitors of CTLA-4 and PD1 were unsuccessful in mesothelioma, according the recently presented PembROlizuMab Immunotherapy Versus Standard Chemotherapy for Advanced prE-treated Malignant Pleural Mesothelioma (PROMISE-meso) trial and the DETERMINE study, wherein the effectivity of Tremelimumab (anti-CTLA-4) as second or third-line treatment was investigated in relapsed malignant mesothelioma patients. ${ }^{3}$ Therefore, it is important that a limited TCR $\beta$ repertoire diversity in total $\mathrm{CD}^{+} \mathrm{T}$ cells correlates with clinical benefit not only in checkpoint-inhibitor treatment, but also in DC-mediated immunotherapy.

Our TCR $\beta$ repertoire analysis showed that DC-therapy mainly shapes the $\mathrm{PD} 1^{+} \mathrm{CD} 8^{+} \mathrm{T}$ cell population and that the clinical response to therapy is particularly linked to $\mathrm{CD}^{+} \mathrm{T}$ cell function. Therefore, it seems valuable to profile TCR repertoire changes in specific T cell subsets, certainly because correlations between TCR repertoire changes and clinical outcome may be obscured by differential effects of immunotherapy on individual $\mathrm{T}$ cell subpopulations. We chose to separately analyze the TCR repertoire in $\mathrm{PD}^{-}$and $\mathrm{PD}^{+} \mathrm{T}$ cells, because this coinhibitory marker is not only a hallmark of exhausted $\mathrm{T}$ cells, but it is also transiently expressed on activated T cells and identifies the $\mathrm{CD}^{+}$tumor-reactive repertoire. ${ }^{27}$ Given the limited number of patients analyzed in this study, our findings need to be validated in a larger and independent DC-therapy cohort. Validation studies in a larger cohorts, will indicate which predictive TCR parameter correlates best with clinical outcome, and should indicate additional associations between demographic data and clinical response.

In summary, with this study we showed that DC-therapy in MPM patients specifically induced TCR $\beta$ repertoire changes in $\mathrm{PD}^{+} \mathrm{CD}^{+} \mathrm{T}$ cells that correlate with clinical outcome. Additionally, high average TCR $\beta$ clone sizes in total $\mathrm{CD}^{+} \mathrm{T}$ cells before the start of immunotherapy were associated with a better clinical response. Therefore, TCR $\beta$ repertoire profiling in both total $\mathrm{CD}^{+}{ }^{+} \mathrm{T}$ cells as sorted $\mathrm{T}$ cell subsets could serve as a biomarker to monitor or to predict the responses of patients to treatment.

\section{Author affiliations}

${ }^{1}$ Pulmonary Medicine, Erasmus Medical Center, Rotterdam, The Netherlands

${ }^{2}$ Cancer Institute, Erasmus Medical Center, Rotterdam, The Netherlands

${ }^{3}$ Clinical Immunology \& Rheumatology, Amsterdam UMC - Locatie AMC, Amsterdam, The Netherlands

${ }^{4}$ Experimental Immunology, Amsterdam UMC - Locatie AMC, Amsterdam, The Netherlands

${ }^{5}$ Laboratory of Genome Analysis, Amsterdam UMC - Locatie AMC, Amsterdam, The Netherlands

${ }^{6}$ Clinical Epidemiology, Amsterdam UMC - Locatie AMC, Amsterdam, The Netherlands

Correction notice Since the online publication of this article, the article was updated to show that shared first authorship is shared between Heleen Vroman and 
Giulia Balzaretti.

\section{Twitter Ilse T G Niewold @\|lssjuh}

Contributors HV, GB, PLK, JGJVA, NdV and RWH designed the project. HV, MvN, GB and ITGN performed experiments, HV and GB analyzed data. BDvS assisted with the bioinformatical acquisition of the data. RB, RC and JGJVA performed patient selection, clinical trial design and provided the clinical data. HV, GB and RWH wrote the manuscript. All patients have read and approved the final manuscript.

Funding This work was carried out on the Dutch national e-infrastructure with the support of SURF Foundation. This study was funded financially by a KWF/ZonMW grant (nr 95104006) and by Amphera BV, The Netherlands.

Competing interests JGJVA reports receiving commercial grants from Amphera, holds ownership interests (including patents) in Amphera BV, and is a consultant/ advisory board member for Amphera.

\section{Patient consent for publication Not required.}

Ethics approval The study was approved by the Central Committee on Research involving Human Subjects (NL4433000014) as defined by the Medical Research Involving Human Subjects Act. Procedures followed were in accordance with the ethical standards of these committees on human experimentation and with the Helsinki Declaration of 1975, as revised in 2008.

Provenance and peer review Not commissioned; externally peer reviewed.

Data availability statement Data are available upon reasonable request. All data relevant to the study are included in the article or uploaded as supplementary information. All data associated with this research are present in the paper or the Supplementary Materials.

Open access This is an open access article distributed in accordance with the Creative Commons Attribution Non Commercial (CC BY-NC 4.0) license, which permits others to distribute, remix, adapt, build upon this work non-commercially, and license their derivative works on different terms, provided the original work is properly cited, appropriate credit is given, any changes made indicated, and the use is non-commercial. See http://creativecommons.org/licenses/by-nc/4.0/.

\section{ORCID iD}

Heleen Vroman http://orcid.org/0000-0002-4392-935X

\section{REFERENCES}

1 Yap TA, Aerts JG, Popat S, et al. Novel insights into mesothelioma biology and implications for therapy. Nat Rev Cancer 2017;17:475-88.

2 Patel SA, Minn AJ. Combination cancer therapy with immune checkpoint blockade: mechanisms and strategies. Immunity 2018;48:417-33.

3 Maio M, Scherpereel A, Calabrò L, et al. Tremelimumab as secondline or third-line treatment in relapsed malignant mesothelioma (determine): a multicentre, international, randomised, double-blind, placebo-controlled phase 2B trial. Lancet Oncol 2017;18:1261-73.

4 Alley EW, Lopez J, Santoro A, et al. Clinical safety and activity of pembrolizumab in patients with malignant pleural mesothelioma (KEYNOTE-028): preliminary results from a non-randomised, openlabel, phase 1B trial. Lancet Oncol 2017;18:623-30.

5 Quispel-Janssen J, van der Noort V, de Vries JF, et al. Programmed death 1 blockade with nivolumab in patients with recurrent malignant pleural mesothelioma. J Thorac Oncol 2018;13:1569-76.

6 Coussens LM, Zitvogel L, Palucka AK. Neutralizing tumor-promoting chronic inflammation: a magic bullet? Science 2013;339:286-91.

7 Marcq E, Siozopoulou V, De Waele J, et al. Prognostic and predictive aspects of the tumor immune microenvironment and immune checkpoints in malignant pleural mesothelioma. Oncoimmunology 2017;6:e1261241.
8 Minnema-Luiting J, Vroman $\mathrm{H}$, Aerts J, et al. Heterogeneity in immune cell content in malignant pleural mesothelioma. Int $\mathrm{J} \mathrm{Mol} \mathrm{Sci}$ 2018;19. doi:10.3390/ijms19041041. [Epub ahead of print: 30 Mar 2018].

9 Cornwall SMJ, Wikstrom M, Musk AW, et al. Human mesothelioma induces defects in dendritic cell numbers and antigen-processing function which predict survival outcomes. Oncoimmunology 2016;5:e1082028.

10 Hegmans JP, Veltman JD, Lambers ME, et al. Consolidative dendritic cell-based immunotherapy elicits cytotoxicity against malignant mesothelioma. Am J Respir Crit Care Med 2010;181:1383-90.

11 Aerts JGJV, de Goeje PL, Cornelissen R, et al. Autologous dendritic cells pulsed with allogeneic tumor cell lysate in mesothelioma: from mouse to human. Clin Cancer Res 2018;24:766-76.

12 de Goeje PL, Klaver Y, Kaijen-Lambers MEH, et al. Autologous dendritic cell therapy in mesothelioma patients enhances frequencies of peripheral CD4 T cells expressing HLA-DR, PD-1, or ICOS. Front Immunol 2018;9:2034.

13 Hopkins AC, Yarchoan M, Durham JN, et al. T cell receptor repertoire features associated with survival in immunotherapy-treated pancreatic ductal adenocarcinoma. JCI Insight 2018;3.

14 Formenti SC, Rudqvist N-P, Golden E, et al. Radiotherapy induces responses of lung cancer to CTLA-4 blockade. Nat Med 2018;24:1845-51.

15 Takeda K, Kitaura K, Suzuki R, et al. Quantitative T-cell repertoire analysis of peripheral blood mononuclear cells from lung cancer patients following long-term cancer peptide vaccination. Cancer Immunol Immunother 2018;67:949-64.

16 Wieland A, Kamphorst AO, Adsay NV, et al. T cell receptor sequencing of activated CD8 T cells in the blood identifies tumorinfiltrating clones that expand after PD-1 therapy and radiation in a melanoma patient. Cancer Immunol Immunother 2018;67:1767-76.

17 Riaz N, Havel JJ, Makarov V, et al. Tumor and microenvironment evolution during immunotherapy with nivolumab. Cell 2017;171:934-49.

18 Hopkins AC, Yarchoan M, Durham JN, et al. T cell receptor repertoire features associated with survival in immunotherapy-treated pancreatic ductal adenocarcinoma. JCI Insight 2018;3:1-10.

19 Hsu M, Sedighim S, Wang T, et al. Tcr sequencing can identify and track Glioma-Infiltrating T cells after DC vaccination. Cancer Immunol Res 2016;4:412-8.

20 Carreno BM, Magrini V, Becker-Hapak M, et al. Cancer immunotherapy. A dendritic cell vaccine increases the breadth and diversity of melanoma neoantigen-specific T cells. Science 2015;348:803-8.

21 Sheikh N, Cham J, Zhang L, et al. Clonotypic diversification of intratumoral $\mathrm{T}$ cells following sipuleucel-T treatment in prostate cancer subjects. Cancer Res 2016;76:3711-8.

22 Hogan SA, Courtier A, Cheng PF, et al. Peripheral blood TCR repertoire profiling may facilitate patient stratification for immunotherapy against melanoma. Cancer Immunol Res 2019;7:77-85.

23 Cha E, Klinger M, Hou Y, et al. Improved survival with T cell clonotype stability after anti-CTLA-4 treatment in cancer patients. Sci Transl Med 2014;6:238ra70.

24 Tumeh PC, Harview CL, Yearley JH, et al. PD-1 blockade induces responses by inhibiting adaptive immune resistance. Nature 2014;515:568-71.

25 Manuel M, Trédan O, Bachelot T, et al. Lymphopenia combined with low TCR diversity (divpenia) predicts poor overall survival in metastatic breast cancer patients. Oncoimmunology 2012;1:432-40.

26 Cha E, Fong L. Shuffling the deck with CTLA-4 therapy: deep sequencing of rearranged TCRB genes demonstrates T cell repertoire remodeling in cancer patients. Oncoimmunology 2018;7:e956016.

27 Gros A, Robbins PF, Yao X, et al. PD-1 identifies the patient-specific $\mathrm{CD}^{+}$tumor-reactive repertoire infiltrating human tumors. J Clin Invest 2014;124:2246-59. 
Correction: $T$ cell receptor repertoire characteristics both before and following immunotherapy correlate with clinical response in mesothelioma

Vroman H, Balzaretti G, Belderbos RA, et al. T cell receptor repertoire characteristics both before and following immunotherapy correlate with clinical response in mesothelioma. J Immunother Cancer 2020;8:e00251. doi: 10.1136/jitc-2019-000251.

Since the online publication of this article, the article was updated to show that shared first authorship is shared between Heleen Vroman and Giulia Balzaretti.

Open access This is an open access article distributed in accordance with the Creative Commons Attribution Non Commercial (CC BY-NC 4.0) license, which permits others to distribute, remix, adapt, build upon this work non-commercially, and license their derivative works on different terms, provided the original work is properly cited, appropriate credit is given, any changes made indicated, and the use is non-commercial. See http://creativecommons.org/licenses/by-nc/4.0/.

C Author(s) (or their employer(s)) 2020. Re-use permitted under CC BY-NC. No commercial re-use. See rights and permissions. Published by BMJ.

J Immunother Cancer 2020;8:e000251corr1. doi:10.1136/jitc-2019-000251corr1

A) Check for updates 